\title{
Political Orientation of Dayak Siang Society In The Election of A Head of Sub-District In Saripoi Sub-District Murung Raya, Central Kalimantan
}

\author{
Novalia Kristin Anjellina, ${ }^{1}$ Setia Budhi, ${ }^{1}$ Jamaluddin ${ }^{1}$, Andi Tenri Sompa ${ }^{1}$, Budi Suryadi ${ }^{1}$ \\ 1, Universitas Lambung Mangkurat, Indonesia \\ Received: 5 March 2021 \\ Article Info \\ Accepted: 25 March $2021 \quad$ Published: 9 April 2021
}

Keywords:
Political Orientation
Cognitive
Affective
Evaluative
Political culture

Copyright and License:

Authors retain copyright and grant the journal right of first publication with the work simultaneously licensed under a Creative Commons Attribution 4.0 International License that allows others to share the work with an acknowledgment of the work's authorship and initial publication in this journal.

\section{INTRODUCTION}

Democracy is a form of government that has been adopted by a number of developed and developing countries around the world to regulate the running of governments, including one in Indonesia. Aristotle, an ancient Greek philosopher, pioneered the basic concept of democracy, believing that democracy was the highest power and the pinnacle of the entire community, including the poor. A democratic country believes that the community or the people are the highest holders of power in a country's government system (Sitepu, 2012). 
Democration encourages all people to participate in the success of the General Election (Election, with the goal of expressing the will of the people in an Election system that is also a democratic procedure for selecting leaders based on the will of the people). Elections are intended to direct the community's political understanding and to serve as a forum for channeling aspirations. as well as their desire as citizens in the Presidential Election, Regional Head Election, and Legislative Election Regional Head Election (Pilkada) is a system for directly electing a regional head and deputy based on Indonesian Law No. 32 of 2004 on Regional Government, according to the first point in Achmad and Budi Suryadi (2009).

The implementation of regional head elections in regions, particularly in areas with indigenous peoples, cannot be divorced from the history of Indonesia, which has many ethnic groups, races, and languages, as well as a diverse indigenous population. Customary words rich in culture and norms born of daily habits have different perspectives on playing a political role. Because, in indigenous peoples' traditions, it is not always possible to apply it as it was in the general community at the time of the General Election. The role of customary and traditional leaders in making policies for their citizens is very important in determining an indigenous group's political orientation. Dayak Siang are the indigenous people who live in Tanah Siang District, Murung Raya Regency, Central Kalimantan. The Dayak Siang tribe is the original Puruk Cahu community and is spread throughout Murung Raya Regency. The Dayak Siang community, like the Dayak people in general, live in groups and farms. As Indonesian citizens, the Dayak Siang community participates in political activities such as voting in the General Election, which is held every five years, and in the implementation of elections in Murung Raya, particularly the Dayak Siang community in Saripoi Sub-district, which always wins candidate pairs from the same party faction and family background as the 200 .

According to data from the KPU in Murung Raya Regency, there were 77,395 people who participated in the election for the Regent and Deputy Regent in Murung Raya, Central Kalimantan, in 2018. The number of ballots punched, but the valid votes received by the General Election Commission (KPU) is only 53,918, of the total number of voters registered as the final voter list (DPT), DPPH, and DBPT at the KPU are 81,623 people, which when presented then the level of public participation in the 2018 Election for Indonesia is 66.06 percent of the total number of voters, whereas in 2013 the number was 66.06 percent of the total number of voters.

The number of permanent voters in the 4 (four) direct elections held by the KPU in Murung Raya Regency, Saripoi Sub-district in 2018 was 928, with a participation percentage of 95.5 percent of the total number of permanent voters. The elected regent, namely Drs. Perdie M. Yoseph, M. Ap (2013-2018, and continued again in 2018-2023), previously in the 2003 and 2008 Pilkada won by Dr. Ir. Willy M. Yoseph, MM for two periods (2003-2008, and 2008-2013), who was the older brother of the elected Regent in 2018 with the PDI-P party faction which became the parent party of the two brothers to advance. The election of Dr. Ir. Willy M. Yoseph, MM, who served from 20032008 and then again in 2008-2013, and then Drs. Perdie M. Yoseph, M.Ap, who served from 20132018 and will continue as Regent from 2018 to 2023, each serving for two terms, and the percentage of elections in Saripoi Sub-district in the 2013 and 2018 Pilkadas that always exceeded 90 percent of the vote who supported the candidate pairs Essentially, the purpose of this study is to gather and verify accurate information in accordance with the stated problems, namely to determine the political 
orientation of the Dayak Siang community in the Regional Head Election in Saripoi Sub-district, Murung Raya Regency.

\section{METHODOLOGY}

This study applied field research. According to Moleong (Lutma Ranta; 2013), field research is a method of collecting empirical data in the field. It is also considered a broad approach in qualitative research or a method for collecting detailed qualitative data. As a result, the authors go directly to the field, specifically to Saripoi Sub-district, to collect data and also carefully approach the subject of research. The research strategy employed was the qualitative one, with the objective of describing and summarizing various conditions, situations, and phenomena of reality that occur in the community in which this research is conducted (Sugiyono; 2008). This method was chosen to extract additional information about the dayak community's political orientation during the conduct of regional head elections. To learn more about the factors that influence a community's choice of regional leader, the role of political parties in securing a pair of candidates, and the role of community leaders in implementing the 2018 General Election, click here. The authors located this study based on the formulation of the problem and also on the fact that the author had previously conducted research in this area, which made it easier for writers to locate data and sources for the data's accuracy and relationship to the theory under investigation. As a result, the authors' research takes place in Saripoi Sub-district, Tanah Siang District, Murung Raya Regency, Central Kalimantan.

\section{FINDINGS AND DISCUSSION}

Political orientation is a pattern of community behavior in relation to state life, state administration, government politics, law, customs, and norms that all members of society follow on a daily basis. Political orientation can also be defined as a society's shared value system that enables it to participate in collective decision-making and public policy formulation for the benefit of the entire community. Political orientation is an individual's "inside" behavior, whereas "outside" behavior takes the form of activities; this distinction is critical because individual orientation is not always manifested in their behavior; political orientation remains at the level of individual abstract thought, but after that, a political participation is formed. and individuals' political behavior (Surbakti, 2010: 141).

The term "political orientation" encompasses a wide range of concepts, including seeing, knowing, perspectives, opinions, judgment attitudes, knowledge, and beliefs. Almond and Verba define political culture as a characteristic citizen orientation toward the political system and its various components, as well as attitudes toward the role of citizens within that system. Distribution of patterns of specific political orientations among a nation's peoples. Additionally, they stated that citizens always identify with state symbols and institutions in accordance with their orientation, and with that orientation, they evaluate and question their place and role in the political system (Mujiharta, 2005).

Naturally, discussing political orientation will entail a discussion of two issues: an orientation centered on the general prosperity of the populace and an orientation centered on the political elite's power. Political elites who rely solely on power, whose performance is based entirely on obtaining power and the highest level of recognition, political elites who frequently abuse their power are elites who own capital or businesses that can influence the state's life (Damsar, 2012: 78).

A country's democratic culture cannot be said to be successful if its power holders or political elites are incapable of carrying out their responsibilities properly. Another critical point to remember 
is that democracy encompasses not only order and procedure, but also content, behavior, communication, interaction, and values in the management of a political system.

Almond and Verba (1984) formulate a classification of the types of political orientation, in political culture it contains three components of political objects as follows:

a. Cognitive components

Cognitive components, namely components that concern knowledge about politics and belief in politics, its roles and all its obligations;

b. Affective

The affective component is a feeling of the political system or its role, its actors and their appearance;

c. Evaluative

The evaluative component is judgments and opinions about political objects which usually involve standard values on political objects and events.

These three components are not separated to form an assessment of a political object, a person must of course have adequate knowledge about that object, but this knowledge must have been influenced, colored, formed by one's own feelings. Conversely, knowledge of political objects can also shape or color one's feelings towards the political object (Sastroatmodjo, 1995: 37).

Almond and Verba (1984: 18) classify the dimensions of political orientation into several political objects, namely:

1. The system as a general object, provides an understanding of the system as a whole including certain feelings such as patriotism, alienation, cognition and evaluation of a nation as well as understanding and evaluation of governance;

2. Input objects include structures that are intensely involved in the input process, namely political parties, interest groups, and communication media, and show the flow of demands and the process of converting demands from society to government and the process of converting those demands. towards authoritative policies;

3. Output objects, refers to the process by which the policy is implemented or strengthened, the structures that are actively involved are the bureaucracy and the judiciary;

4. Individuals as objects, regarding the content and quality of one's own abilities as political actors, as well as the norms of one's political obligations in the political system.

Referring to the theory of Almond and Verba (1984) to formulate a classification of the types of political orientation, political culture contains three components of political objects as follows:

a. Cognitive components

Cognitive components, namely components that concern knowledge about politics and belief in politics, its roles and all its obligations;

b. Affective

The affective component is a feeling of the political system or its role, its actors and their appearance.

c. Evaluative

The evaluative component is judgments and opinions about political objects which usually involve standard values on political objects and events.

The three (3) components of political orientation described by Almond \& Verba (1984) can draw conclusions for the creation of a conceptual framework in this study.

Political orientation is a way of viewing class society in the structure of society. The values contained in the community that then form the attitude and become patterns of people looking at the object of political orientation (Election Commission Madina accessed on 10 January 2020) are the 
background behind the orientation of politics. Political orientation is closely related to political culture and ideology politics are inherent in a group of people who are formed that will be able to see the result orientation of the politics of voters based on the types of orientation which Almond and Verba (1984) has described.

From this type of political orientation, the output will be in the form of the results of the General Election which will be held in Saripoi Sub-district, so that we can classify it into the type of political orientation that Dayak Siang people take and whether political culture and political ideology affect the orientation of voters in making decisions during the General Election.

The political orientation that is discussed in the author's research conducted in Tanah Siang, Saripoi sub-district, is in fact influenced by several factors that eventually form a pattern and become a culture in the voting community, when referring to the type of orientation described by Almond and Verba (1984) who formulated the classification of the types of political orientation which contains three components of political objects including cognitive, affective and evaluative components, the following results are obtained:

\section{a. Cognitive component}

The cognitive component in political orientation according to Almond and Verba (1984) is a component that concerns political knowledge and belief in politics, its roles and obligations as well as its inputs and outputs; This component is used to determine the direction of the political orientation of a group or individual in society in determining their political choices which will later lead to political culture as it is further grouped into 3, namely parochial political culture, subjects and participants.

The focus of the research that the researchers carried out was only limited to knowing the political orientation of the Dayak Siang community according to the 3 components raised by Almond and Verba, so that what researchers want to know is the political orientation of the cognitive components of the Dayak Siang community in Saripoi Sub-district, so that what factors can be found encourage and influence the political orientation of the community.

The cognitive component that concerns knowledge about politics and belief in politics according to the Dayak Siang community in Saripoi in interviews conducted with sources, the Dayak Siang community has knowledge about politics, such as recognizing and being able to distinguish existing political parties, recognizing state symbols such as the Indonesian flag. It has 2 colors, namely red and white, people tend to find knowledge about politics through mass media such as Baleho which was posted during the campaign before the Election and obtained from watching TV or online / online such as Facebook and from mouth to mouth.

During field observations the researchers also visited the community with smaller groups, namely groups of people who spent a lot of time living in fields far from Saripoi Sub-district and the public's knowledge of politics in general was quite good, they recognized political symbols and political parties with such information. mostly obtained by word of mouth.

Public trust in politics in the cognitive component is understood by the Dayak Siang community by providing support to the government, in this case participating in village development planning deliberations (musrembang) and other activities. In this case, most Dayak Siang people only believe in a political system that operates and follows orders. It's just that the supervisory function is still lacking in Dayak Siang community. This can be seen from the main road in Saripoi Sub-district, which is still ugly and there has been no real effort from the community to urge the government to immediately carry out road repairs. 
People who have a fairly good political education background and jobs that have a relationship with the government, in this case people in large groups shift their belief in politics into trust in certain individuals or political actors who are able to lead public opinion so that it "seems" to make voters feel that they are quite satisfied with the conditions they are living in now, in the sense that the village head and the head of the family are the determinants of voter decisions in making policies during the General Election.

Overall regarding the political orientation of the cognitive component, the Dayak Siang community in Saripoi Sub-district already know the basics of the cognitive component as explained by Almond and Verba (1984) from community groups living in Saripoi Sub-district to people living in the fields.

\section{b. Affective component}

The affective component is one of the components in the political orientation described by Almond and Verba (1984). In their theory, they explain that the effective component is the feeling of the political system or its role, the actors and their appearance; Concerning the affective component that is understood by the Dayak Siang community, it is a support for candidates for Regional Head with the same background, in this case ethnic and religious backgrounds. The community understands that the same language and ethnic background is political, this was explained by the informants that the understanding of language and culture from political actors will greatly influence the political orientation of the community later.

The ethnic and linguistic background of the Dayak Siang community is very important, by winning a candidate from the same ethnic and linguistic background can make it a symbol of success for the community. The support given by the Dayak Siang community in Saripoi by casting their votes in elections is considered appropriate to be given to someone with the same ethnic background as a form of support from the community. This was also conveyed by DAD secretary Murung Raya who said that the Siang tribe was a "racist" society.

Feelings about the political system that are included in the affective component of political orientation proposed by Almond and Verba (1984) also explain that in the process of understanding politics in certain groups of people have different views and opinions, such as urban society and indigenous peoples, of course the perspective in Seeing a political system is different and there are certain factors that drive understanding the current political system.

The factors that influence policy making and the feelings of individuals or groups in Dayak Siang society are more or less influenced by customary leaders and traditional elders as well as the influence of the bureaucracy and political elites who are able to lead public opinion in determining the direction of political policy for the community, because In the interviews conducted, the role of the customary head as someone respected by the Dayak Siang customary community is very large in influencing decision-making by the community.

The results of the interview also illustrated that certain groups in the Daya Siang community were satisfied with the current government, the political system was also considered very good and easy to implement by the people in Saripoi Sub-district. The feeling of society in the affective component is most closely related to people's feelings towards political actors, this is explained by the community in interviews and observations made by researchers to the Dayak Siang community, people tend to be more open to only one political actor, the political strategy carried out by the actor This politics has succeeded in making people have confidence in these political actors so that they become more obedient to the political system that is brought into society. 
The affective orientation in Saripoi Sub-district is in accordance with the theory of Almond and Verba (1984), this can be seen from how people admire a political actor with all the political systems they run, so that the political system run by political actors and political elites can be accepted by the community. . The affective component in Saripoi Sub-district is unique, this happens because political actors who have the ability to make people "like" have emotional ties to certain political actors and political elites who are admired by the Saripoi community and most people become voters who are loyal and obedient to actors and the political elite they choose.

\section{c. Evaluative Component}

Evaluative is the final component that an individual or community group must have in determining their political orientation. Evaluative according to Almond and Verba (1984) is decisions and opinions about political objects that typically involve a combination of standard values and criteria between information and feelings of individuals and groups.

The orientation of the Dayak Siang community in this case is in accordance with the evaluative component described by Almond \& Verba in their theory of the component of political orientation, especially among the elderly who are agents of political campaigns in the family, the existence of community emotional ties to political actors or objects plays an important role in affect the evaluative orientation.

The standard of values and criteria for political objects is seen by the community as a necessity to fulfill the wishes of the community in representing their aspirations, the Dayak Siang community in Saripoi Sub-district believes that by fulfilling their criteria for a political actor it is hoped that they will be able to become a "protector" for the community in the future. The results of the interview show that there are several criteria for political actors who are desired by the community, including someone with the same ethnic background, the same language, understanding the needs of the community, and being able to protect and maintain the customs and customs and culture of the Dayak Siang community.

If the theory of Almond and Verba (1984) explains that the evaluation component concerns a policy, decision, or decision strengthening of structures, office holders and structures can reciprocally be grouped whether society takes part in the political "input" process or in the process. administrative "output". The Dayak Siang community understands this according to the evaluative component that should be, but several times in the results of interviews the community emphasizes that the appropriate political actor is someone who has the same ethnic and linguistic background, it is this character standard determination that is continuously being built in society. so that it becomes a pattern in society.

The tendency of the community to choose one actor who conforms to value standards with information and feelings is also supported by the existence of family relationships between voters and political actors who run for themselves, as well as the existence of patron and client relationships in the government bureaucracy in Saripoi Sub-district. These are the things that drive the orientation of the Dayak Siang community in giving their rights to the Pilkada held in 2013 and 2018.

Of the three components above, it can refer to the political orientation of the Dayak Siang community, especially in the Sub-district, which is influenced by the Parochial political culture, this happens because in general the number of people in making decisions in politics still has to be directed by other people, the Head of the Village, the Head of Customs and community leaders. and the role of parents who are used by actors and political elites as their political agents in society and in the family. Although there are politically oriented groups of people who are quite firm in looking 
at the political system and its inputs and outputs, in the end they still have a parochial culture based on the background of customs and norms that exist in society.

The results of observations and interviews with the Dayak Siang community in Saripoi Subdistrict, the authors found several things that were supporting factors in influencing the decision making made by voters in Saripoi Sub-district, including:

a. There is a political image carried out by political elites and political actors that make Dayak Dayak people "willing" to give their political freedom to joint decisions as indigenous peoples. However, in people who understand politics, it is also found that there is a tendency to choose political actors based on "loyalty" even though they have not actually provided suitable welfare for the people in Saripoi sub-district, this is illustrated by the very poor main road to Tanah Siang sub-district since 2004-2019. Until now, there has not been any improvement such as paving the main road and inadequate access to the design for the community. The role of the government, which is still very minimal in socializing politics to the public, has also not been taken seriously.

b. It was found that there were political dynasties and bureaucracy in the political system that ran in Murung Raya, starting from village to district officials. It was found that there was a family relationship between office holders and government officials and political elites in Murung Raya. The head of the Saripoi sub-district stated that political actors make officials in the sub-district and sub-district spearhead to win predetermined candidate pairs by means of an ethnic identity approach and the term "kinship" or "dulun itoh" to voters in Saripoi subdistrict. The winning strategy for the candidate pair for Regent and Deputy Regent number two is in the spotlight not only because this pair is supported by a strong political elite, but also because of the existence of a dynasty of power that has a major influence on the psychology and physiology of voters in determining their choice, this pair also carries out a political strategy that is tends to be at risk by narrowing down "democracy" in the ranks of government, this is evidenced by a direct order from the Regent to win himself in the 2018 General Election to government officials at the village / sub-district level.

c. Customary leaders, community leaders and parents as political agents in the family sphere, the decision of young voters is determined by what their parents say, in this case the Dayak Siang community especially first-time voters will tend to choose based on their parents' choice and open their own decisions, the reason this novice voter gives the right the choice according to the wishes of their parents is because most of the novice voters think that they do not understand and also do not understand the government process, they know that they vote and after that for government activities both in the input and output of political policy and government in general the voters Almost all of these young people do not know and do not care, as long as they have given their voting rights in the General Election it is considered sufficient by novice voters.

d. It was also found the practice of money politics, but in this case, political actors and elites package in such a way that it looks like they are not doing money politics, they call it the term "transfer money" which is given to voters before voting, when the author asks questions This was to government officials in Saripoi sub-district, they said that there was no money politics practice in Saripoi's blood, but maybe in other villages it was true. In the end, the practice of money politics that was carried out could be covered up by the community because the community indeed considered it as transportation money considering the distance, they traveled from their homes to the TPS was quite far. 
This also happened during the 2018 Election, where at a high level of confidence from respondents it was seen that there would be no shift in orientation in making political choices. This means that voters are absolutely sure of their attitude and mindset on the actions taken based on the considerations of parents and blood ties. This stigma will make voters close themselves to various possibilities, including motivation to seek information because it only comes from one direction, voters will cover themselves with various kinds of information related to other candidates or parties, they will open themselves and be motivated to seek information only on candidates or political parties that will be chosen by their parents or those who come from their family ties.

In general, the political culture of the Dayak Siang community is influenced by the decisions of traditional leaders and community leaders as well as their closeness to political actors. The development of the image of political objects is very influential in decision-making by voters, so that the political culture of the political orientation that runs in Saripoi Village, the political culture of the Dayak Siang community is parochial. If the candidates for Regent and Deputy Regent want to conduct a lecture with the Dayak Siang community, it is necessary to understand the background and culture as well as the values and norms that are carried out in the community first.

Basically politics is an important thing in democracy, participation and political culture will greatly influence the political orientation of voters, it is hoped that with an honest and fair election it can encourage political actors to be more responsible with the burden it carries. Through the General Election, it is hoped that equal distribution of political understanding can be felt by all levels of society in Indonesia, but in reality areas with indigenous peoples will have a different political understanding from urban communities, this happens because indigenous peoples will prioritize the values and norms they apply in their culture. and their daily habits as a tribe or custom that applies in their area.

Political decisions made by the government are expected to be able to encourage people to participate in making decisions made and determine the content of political decisions. However, in practice, community participation is very minimal, political parties which are a place for regional head candidates and a place to accommodate the aspirations of the community have now changed roles, many political parties are no longer carrying out their main objectives but instead include the interests of their respective parties and individuals.

The officials who already have power seem to forget their promises to the people, the defense of the people's interests and the people's welfare is slowly being faded from the official agenda, the political elites are present with their own interests, imposing their will on the ruling officials, in the end. It is not the people who are the problem anymore, but the war between political elites and political officials that has surfaced. People only become spectators to see political actors dropping each other, instead of helping each other, in the end it is common for political actors to maintain their power.

\section{CONCLUSION}

Based on research on the political orientation of the Dayak Siang community in Saripoi subdistrict, from 3 components of orientation, namely cognitive, affective, and evaluative orientation, according to Almon and Verba theory (1984), the orientation of the community in determining the political culture that exists in a specific group area, in that... However, the Dayak Siang people in this community have a very good understanding of three main orientations: cognitive, affective, and evaluative orientations, though they are not yet able to use them in political life. 
The practice of Pemilukada in Dayak Siang community also occurred, though there were some people who were apathetic towards the running of the government and the existing political system. However, in the end, the people continued to participate in Pemilukada activities. As a result, the author can identify the Dayak Siang's political orientation based on the findings of his research on the political orientation of the Dayak Siang community, and this has led to a Parochial Political Culture. The traditional leaders and community leaders of the Dayak Siang people can all affect the community's political views because they interact with local and national political actors on a regular basis.

as a result of the findings contained in this study, several new ideas can be developed for the experiment including, but not limited to, ones related to cognitive orientation, such as helping the Dayak Siang tribe people improve their political education, which will enable a greater spread of political awareness within the community. With regard to emotional orientation, it is hoped that after understanding politics, people will be able to put it into practice in social life, such as sharing their aspirations and demands for their rights as a political community. Conceptually, there are two additional approaches, each one quite distinct, that can be adopted: Evaluative orientation (last approach), to increase the citizens' awareness of political matters and the desire to fight for their rights, and the next approach, i. with the aforementioned, a year-round instructional program to increase political understanding and encourage students to express their desires for rights as a people. A year-round instructional program to increase political understanding and an increase in the number of political parties in society so that future students may improve the political quality of the Dayak Siang community.

For the general election in 2024, the writer hopes that Saripoi sub-district residents will be more courageous and more willing to contribute their voting rights according to their understanding and thoughtfulness, making them better able to perform their functions as members of a political society.

\section{REFERENCES}

Almond Gabriel, Sidney Verba. 1984. Budaya Politik Tingkah Laku Politik dan Demokrasi di Lima Negara. Jakarta: Penerbit Bumi Aksara.

Budiardjo, Miriam. (2008a). Dasar-Dasar Ilmu Politik. Jakarta: Gramedia Pustaka Utama.

Budiardjo, Miriam. (2012b). Dasar-Dasar Ilmu Politik. Jakarta: Gramedia Pustaka Utama

Creswell. John. (2015: 58). Penelitian Kualitatif \& Desain risert. Yogyakarta: Pustaka Pelajar.

Henk Schulte, K.V. Gerry dan Karang.Irene (Ed). (2007). Politik lokal di Indonesia Jakarta. Yayasan Obor Indonesia. Jamie S. Davidson, Henley, David dan Moniaga, Sandra (Ed). (2010). Adat dalam Politik Indonesia. Jakarta: Yayasan Pustaka Obor Indonesia.

Jaharudin, Mohd Hariszuan. 2014. Pilihan Raya Umum Ke-13: Perubahan Budaya Politik Malaysia dan Krisis Legitimasi Moral Barisan Nasional. Jurnal, 32 (2): 149-169.

Kamarusdiana. (2019). Studi Etnografi Dalam Kerangka Masyarakat Dan Budaya (Community and Cultural Framework in Ethnographic Studies) Universitas Islam Negeri Syarif Hidayatullah Jakarta, Indonesia. Vol.6, no.02

Ma'rifah, Yusfirlana, Warsono. (2014) Orientasi Politik Politisi Etnis Cina Di Kota Surabaya Pada Pemilu 2004 Dan 2009. Vol. 1, No 2, h. 8-10

Martien Herna Susanti, (2017). Dinasti Politik dalam Pilkada di Indonesia Vol, 1, no. 2. Link: jurnal.umt.ac.id/index.php/jgs/article/view/440 Madlyn, M Marry. (2019). Political Orientation and Belief in Science in a U.S. College Sample. University of Southern Mississippi.

Mujani, Saipul. (2007).Muslim demokrat: Islam, budaya demokrasi, dan partisipasi politik di Indonesia pasca Orde Baru Jakarta: Gramedia Pustaka .

Mulkhan, Abdul Munir. (2003). Moral politik santri: agama dan pembelaan kaum tertindas, Jakarta: Erlangga. 
Mulyawan, Budi. 2015. Budaya Politik Masyarakat Indonesia Dalam Perspektif Pembangunan Politik. Jurnal Aspirasi, 5 (2): 2287-2208.

Sadiani. (2014). Peran Lembaga Adat Kedemangan Dayak Siang Dalam Penyelesaian Sengketa Pemanffatan Kawasan Hutan Adat Puruk Kambang Di Kabupaten Murung Raya. Disertasi. Malang ;Universitas Brawijaya,

Sitepu. Anthonius. (2012). Study Ilmu Politik. Yogyakarta: Graha Ilmu.

Suleman.Zulfikri. (2010). Demokrasi untuk Indonesia: pemikiran politik Bung Hatta. Jakarta: Kompas Media Utama.

W. Mantja. (2003) Etnografi Disain Penelitian Kualitatif dan Manajemen Pendidikan. Malang : Winaka Media.34

Warjio. (2016). Politik Pembangunan: paradoks, teori, aktor, dan ideology. Jakarta: Kencana. 